Article

\title{
Biodiesel-Derived Glycerol Obtained from Renewable Biomass-A Suitable Substrate for the Growth of Candida zeylanoides Yeast Strain ATCC 20367
}

\author{
Laura Mitrea ${ }^{1}$, Floricuța Ranga ${ }^{1}$, Florinela Fetea ${ }^{1}$, Francisc Vasile Dulf ${ }^{2}{ }^{\circledR}$, Alexandru Rusu ${ }^{3}$, \\ Monica Trif $1, *$ (D) and Dan Cristian Vodnar $1, *$ (D) \\ 1 Institute of Life Sciences, Faculty of Food Science and Technology, University of Agricultural Sciences and \\ Veterinary Medicine, Cluj-Napoca, Calea Mănăștur 3-5, 400372 Cluj-Napoca, Romania \\ 2 Faculty of Agriculture, University of Agricultural Sciences and Veterinary Medicine Cluj-Napoca, \\ Calea Mănăștur 3-5, 400372 Cluj-Napoca, Romania \\ 3 CENCIRA Agrofood Research and Innovation Centre, 6/66 Ion Mester Street, 400650 Cluj-Napoca, Romania \\ * Correspondence: monica_trif@hotmail.com (M.T.); dan.vodnar@usamvcluj.ro (D.C.V.); \\ Tel.: +49-172-41-86193 (M.T.); +40747341881 (D.C.V.)
}

Received: 6 August 2019; Accepted: 15 August 2019; Published: 16 August 2019

check for updates

\begin{abstract}
Used kitchen oil represents a feasible and renewable biomass to produce green biofuels such as biodiesel. Biodiesel production generates large amounts of by-products such as the crude glycerol fraction, which can be further used biotechnologically as a valuable nutrient for many microorganisms. In this study, we transesterified used kitchen oil with methanol and sodium hydroxide in order to obtain biodiesel and crude glycerol fractions. The crude glycerol fraction consisting of $30 \%$ glycerol was integrated into a bioreactor cultivation process as a nutrient source for the growth of Candida zeylanoides ATCC 20367. Cell viability and biomass production were similar to those obtained with batch cultivations on pure glycerol or glucose as the main nutrient substrates. However, the biosynthesis of organic acids (e.g., citric and succinic) was significantly different compared to pure glycerol and glucose used as main carbon sources.
\end{abstract}

Keywords: renewable biomass; used kitchen oil; crude glycerol; organic acids; Candida zeylanoides; fermentations

\section{Introduction}

Green biofuels have gained the attention of researchers in the last decades, not only because of the imminent exhaustion of the fossil fuels, but also due to the renewable biomass' potential to be converted into bio-combustibles with high efficiency [1,2]. Biofuels, and particularly biodiesel, can be successfully produced from biomass through catalytic reactions [3-5]. Biodiesel, which is an important exponent of eco-friendly biofuels, is produced in large quantities around the globe and especially in Europe, which is the leader in the context of biodiesel production market [6,7]. One of the major advantages of biodiesel is given by its non-toxicity and its minimal greenhouse gas emissions [8].

Biomass is presented as a renewable resource for bioenergy and biochemical production $[9,10]$. It mostly consists of wood wastes, agricultural crops and their waste derivatives, municipal solid wastes, animal wastes, and residues deriving from food and aquatic plant processing industries; all these can be sources of biogenic and renewable biomaterials and biofuels [9,11-16]. From the economical point of view, recycled oils and greases resulting from the food sector represent a feasible alternative source of renewable biomass for the biodiesel industry [9,17]. Massive quantities of used 
kitchen oils and greases are generated worldwide, and in technologically-advanced countries in particular, their disposal is causing important environmental issues [18]. Reusing the used kitchen oils via biotechnological processes with the purpose of producing biofuels, biomaterials, and biochemicals is a step forward in the reduction of environmental pollution caused by their random discharge [19]. Moreover, using recycled kitchen oils in the biofuels industry as feedstock material instead of edible oils (e.g., canola, soybean, sunflower, palm oils) might avoid the competition between the exploitation of lands for food versus energy [19-22].

The triglycerides from vegetal or animal sources can be efficiently converted into biodiesel through a variety of procedures, such as direct mixtures with solvents, micro-emulsions, pyrolysis, and transesterification [23-26]. The biodiesel phase consisting of fatty acids methyl/ethyl esters is mostly achieved through transesterification using various catalysts [27]. The transesterification reaction and the quality of the final products depend significantly on the catalyst type (alkaline (sodium hydroxide, sodium methoxide, potassium hydroxide) vs. acidic (sulfuric acid, sulphonic acid, hydrochloric acid) vs. enzymatic (lipase)) and its concentration [20,24,28-30]. During transesterification, the ester bonds between fatty acids and glycerol break down, and the free fatty acids bind to other alcohol molecules present in the reaction medium. At the end of the transesterification process, the reaction mixture contains an amalgam of fatty acids, methyl/alkyl esters, and glycerol [31]. Regardless of the procedure used in the manufacturing of biodiesel, extensive amounts of by-products (e.g., crude glycerol) are generated, and the surplus of this fraction presents environmental challenges associated with its disposal [19,32,33].

In the biotechnological context, crude glycerol represents a valuable matrix that can be exploited for the bio-production of chemicals with health [5,34] or industrial potential [26,35-38]. Bacteria, fungi, yeasts, and algae can metabolize biodiesel-derived crude glycerol and convert it into organic acids, propane-diols, carotenes, poly-unsaturated fatty acids, proteins, lipids, etc. [5,26,34,38,39]. Fungal and yeast strains such as Aspergillus, Rhizopus, Yarrowia or Candida are mostly cultivated for their ability to transform the crude glycerol fraction into bio-chemicals with food applicability: organic acids (citric, succinic, malic acids), low caloric polyols (arabitol, erythritol, mannitol), or single-cell oils [40]. Multiple studies have been conducted on crude glycerol using yeasts such as Candida or Yarrowia to produce feedstock chemicals such as citric and succinic acids [41] under steady-state conditions and under different grades of aeration [42,43]. Some of the Yarrowia and the Candida species (Yarrowia lipolytica, Candida tropicalis, Candida guilliermondii, Candida parapsilopsis, Candida oleophila, Candida zeylanoides) are well-known as adaptable microorganisms to fats, oils, fatty acids or hydrocarbons containing medium $[40,43]$ because of their ability to metabolize hydrophobic substrates $[44,45]$.

In the context of pollution reduction, crude glycerol derived from biodiesel production using recycled kitchen oils represents a suitable medium for cultivating microorganisms such as Candida spp. The main purpose of this work was to evaluate the adaptation mechanisms of C. zeylanoides ATCC 20367 cells to a cultivation medium that contains only crude glycerol as an energy source and their potential to bio-synthesize citric and succinic acids. Crude glycerol obtained from recycled kitchen oil by alkali transesterification was used as a single energy substrate, and analytical grade glycerol and glucose were used as comparators for cell viability and metabolites production.

\section{Materials and Methods}

\subsection{Materials}

Except for crude glycerol fraction, all the culture media components were of analytical grade and purchased from VWR International (Radnor, Pennsylvania, PA, USA).

The crude glycerol fraction was obtained from recycled vegetable cooking oil through an alkali transesterification process. The fried sunflower oil collected from the household was mixed with methanol and $\mathrm{NaOH}$. The inferior phase consisting of crude glycerol was collected after $48 \mathrm{~h} \mathrm{[46]} \mathrm{and}$ used as a nutrient substrate for batch fermentations. Before the addition to fermentation medium, 
the $\mathrm{pH}$ of the crude glycerol fraction was adjusted to 7 by adding a few drops of $2 \mathrm{M} \mathrm{HCl}$, and it was measured with a laboratory $\mathrm{pH}$ meter, model InoLab. The crude glycerol fraction was sterilized separately at $121^{\circ} \mathrm{C}$ for $20 \mathrm{~min}$.

\subsection{Microorganism and Culture Media}

C. zeylanoides ATCC 20367 purchased from American Type Culture Collection (Manassas, Virginia, VA, USA) was used in the present work for all the experiments. The yeast strain was maintained on yeast malt extract agar plates (at $1 \mathrm{~L}$ distilled water: yeast extract $3 \mathrm{~g} / \mathrm{L}$, malt extract $3 \mathrm{~g} / \mathrm{L}$, dextrose $10 \mathrm{~g} / \mathrm{L}$, peptone $5 \mathrm{~g} / \mathrm{L}$, agar $20 \mathrm{~g} / \mathrm{L}$ ) at $4{ }^{\circ} \mathrm{C}$ and renewed periodically every $2-3$ months.

Culture media components and cultivation conditions were adapted after Takayama et al. [47]. The inoculums representing $10 \%$ of the culture were prepared by transferring $10^{7} \mathrm{cfu} / \mathrm{mL}$ into $500 \mathrm{~mL}$ shake flasks with buffers containing $200 \mathrm{~mL}$ of culture media having the components mentioned in Table 1 . The shake flasks were incubated for 2 days at $30^{\circ} \mathrm{C}, \mathrm{pH} 6 \pm 0.2$, and $200 \mathrm{rpm}$. The fermentation process conducted at the bioreactor level contained the same components except for $\mathrm{CaCO}_{3}$.

Table 1. Media components for C. zeylanoides ATCC 20367 growth on pure glycerol, crude glycerol, and glucose.

\begin{tabular}{|c|c|c|c|}
\hline Nutrients & Batch CG & Batch PG & Batch Gl \\
\hline $\mathrm{n}$ paraffin $(\mathrm{mL} / \mathrm{L})$ & 50 & 50 & - \\
\hline Pure glycerol (g/L) & - & 30 & 0.5 \\
\hline Crude glycerol (g/L) & 30 & - & \\
\hline Glucose $(\mathrm{g} / \mathrm{L})$ & - & - & 30 \\
\hline $\mathrm{NH}_{4} \mathrm{Cl}(\mathrm{g} / \mathrm{L})$ & 5 & 5 & 5 \\
\hline $\mathrm{KH}_{2} \mathrm{PO}_{4}(\mathrm{~g} / \mathrm{L})$ & 0.5 & 0.5 & 0.5 \\
\hline $\mathrm{MgSO}_{4}(\mathrm{~g} / \mathrm{L})$ & 0.5 & 0.5 & 0.5 \\
\hline $\mathrm{CaCO}_{3}(\mathrm{~g} / \mathrm{L}) *$ & 80 & 80 & 10 \\
\hline $\mathrm{MnSO}_{4} \times 4 \mathrm{H}_{2} \mathrm{O}(\mathrm{mg} / \mathrm{L})$ & 2 & 2 & 2 \\
\hline $\mathrm{ZnSO}_{4} \times 7 \mathrm{H}_{2} \mathrm{O}(\mathrm{mg} / \mathrm{L})$ & 2 & 2 & 2 \\
\hline $\mathrm{FeSO}_{4} \times 7 \mathrm{H}_{2} \mathrm{O}(\mathrm{mg} / \mathrm{L})$ & 10 & 10 & 10 \\
\hline $\mathrm{CuSO}_{4} \times 5 \mathrm{H}_{2} \mathrm{O}(\mu \mathrm{g} / \mathrm{L})$ & 50 & 50 & 50 \\
\hline Thiamine- $\mathrm{HCl}(\mu \mathrm{g} / \mathrm{L})$ ** & 100 & 100 & 100 \\
\hline
\end{tabular}

CG, crude glycerol; PG, pure glycerol; Gl, glucose. * was sterilized separately and added only in the inoculum media. ${ }^{* *}$ was added to the fermentation broth after sterilization at $121{ }^{\circ} \mathrm{C}$ through sterile filtration $(0.45 \mu \mathrm{m})$.

\subsection{Bioreactor Batch Fermentation}

All experiments were performed in a 5 L bioreactor (Eppendorf, BioFlo 320, one unit, Hamburg, Germany) containing $2 \mathrm{~L}$ of working media. The inoculums were added in sterile conditions. The bioreactor was equipped with $\mathrm{pH}$ and temperature sensors and a rotation speed control. Temperature, $\mathrm{pH}$, and rotations were maintained constant at $30^{\circ} \mathrm{C}, 6.00 \pm 0.2$, and $400 \mathrm{rpm}$, respectively. The $\mathrm{pH}$ was adjusted automatically by adding $45 \% \mathrm{NaOH}$. The fermentation process ran for $163 \mathrm{~h}$ in aerobic conditions. Filtered air (through $0.20 \mu \mathrm{m}$ filters, Macherey-Nagel) was continuously added into fermentation broth by a peristaltic pump (Watson Marlow $520 \mathrm{~S}$, Cornwall, England) settled at $10 \mathrm{rpm}$ and $158 \mathrm{~mL} / \mathrm{min}$. From time to time, sterilized silicone oil was added as an antifoaming agent. Samples were collected to perform specific tests at regular time intervals.

\subsection{Assays}

\subsubsection{Determination of the Fatty Acids from Processed and Unprocessed Vegetable Oil}

The fatty acids content from vegetable oil before and after processing within the kitchen was analyzed by GC. The fatty acids profile of the total lipids was determined by acid-catalyzed transesterification by using $1 \%$ sulphuric acid in methanol $[48,49]$. The methylated fatty acids were determined with a gas chromatograph coupled to a mass spectrometer (model PerkinElmer Clarus 
600 T GC-MS; PerkinElmer, Inc., Shelton, CT, USA) [50]. A $0.5 \mu \mathrm{L}$ sample was injected into a $60 \mathrm{~m} \times$ $0.25 \mathrm{~mm}$ i.d., $0.25 \mu \mathrm{m}$ film thickness SUPELCOWAX 10 capillary column (Supelco Inc., Darmstadt, Germany). The operation conditions were as follows: injector temperature $210^{\circ} \mathrm{C}$; helium carrier gas flow rate $0.8 \mathrm{~mL} / \mathrm{min}$; split ratio $1: 24$; oven temperature $140{ }^{\circ} \mathrm{C}$ (hold $2 \mathrm{~min}$ ) to $220^{\circ} \mathrm{C}$ at $7{ }^{\circ} \mathrm{C} / \mathrm{min}$ (hold $23 \mathrm{~min}$ ); electron impact ionization voltage $70 \mathrm{eV}$; trap current $100 \mu \mathrm{A}$; ion source temperature $150{ }^{\circ} \mathrm{C}$; mass range $22-395 \mathrm{~m} / \mathrm{z}(0.14 \mathrm{scans} / \mathrm{s}$ with an intermediate time of $0.02 \mathrm{~s}$ between the scans). The fatty acids content was identified by comparing their retention times with those of known standards (37 components FAME Mix, Supelco no. 47885-U, Darmstadt, Germany) and the resulting mass spectra to those in the database (NIST MS Search 2.0). The amount of each fatty acid was expressed as a percentage of total fatty acid content.

\subsubsection{Crude Glycerol Analysis by FTIR}

Crude glycerol fraction was analyzed by FTIR (Shimadzu IR Prestige-21, Kyoto, Japan) equipped with an attenuated total reflectance (ATR) module against petroleum ether as the background. The spectra were recorded on a wavelength range of $600-4000 \mathrm{~cm}^{-1}$ at a resolution of $4 \mathrm{~cm}^{-1}$ and 64 scans for a spectrum.

\subsubsection{Biomass and Cell Viability}

Biomass growth was established by measuring the cell dry weight (CDW); $10 \mathrm{~mL}$ of the culture broth was filtered through $0.20 \mu \mathrm{m}$ filters, which were further washed twice with double distilled water and dried at $104^{\circ} \mathrm{C}$ for $8 \mathrm{~h}$.

Yeast cell viability was determined by diluting $1 \mathrm{~mL}$ of fermentation sample in $9 \mathrm{~mL}$ of sterile saline solution $(0.8 \% \mathrm{NaCl})$. Then, $100 \mu \mathrm{L}$ of different dilutions were inoculated on yeast malt extract agar plates and incubated for almost 2 days at $30^{\circ} \mathrm{C}$. The viability of $C$. zeylanoides cells $(\log 10 \mathrm{cfu} / \mathrm{mL})$ was established by plate counting [51]. For microscopic examination of yeast cells, a loop of inoculated fermentation media was put on a glass laboratory lamella, dyed with methylene blue, and examined at $400 \times$ magnification [42,52].

\subsubsection{Organic Acids and Substrate Consumption (Glycerol, Glucose) Determination}

Citric and succinic acids were determined using HPLC (Agilent 1200, Santa Clara, CA, USA) with an Aclaim OA ( $5 \mu \mathrm{m}, 4 \times 150 \mathrm{~mm}$, Dionex, Waltham, MA, USA) reversed-phase chromatographic column coupled with UV detector, solvent degasser, quaternary pumps, column thermostat, and manual injector (Agilent Technologies, Santa Clara, CA, USA). The chromatographic column was eluted for $10 \mathrm{~min}$ with $50 \mathrm{mM} \mathrm{NaH}_{2} \mathrm{PO}_{4}, \mathrm{pH} 2.8$, with a flow rate of $0.5 \mathrm{~mL} / \mathrm{min}$, at $20^{\circ} \mathrm{C}$. The chromatograms were measured at $210 \mathrm{~nm}$.

Glycerol consumption was determined by derivatizing the sample after the method proposed by Imbert et al. [53], as presented in Figure 1, and then analyzed by HPLC. The analytical system consisted of an HPLC Agilent 1200 unit containing a quaternary pump, a solvent degasser, an autosampler, a UV-Vis photodiode detector (DAD) coupled with single quadrupole mass detector (MS, Agilent 6110), equipped with electrospray ionization source (ESI) (Agilent Technologies, California, Santa Clara, CA, USA), and controlled by Agilent ChemStation software. The ESI detection in positive ionization mode was done using the following work conditions: capillary voltage $3100 \mathrm{~V}, 350^{\circ} \mathrm{C}$, nitrogen flow $7 \mathrm{~L} / \mathrm{min}$, $\mathrm{m} / \mathrm{z}$ 100-500 full-scan. The interest compounds separation was performed with an Eclipse XDB C18 column $(5 \mu \mathrm{m}, 4.6 \times 150 \mathrm{~mm}$ I.D.) (Agilent Technologies, California, Santa Clara, CA, USA) using the $20 \mathrm{mM} \mathrm{NH} \mathrm{HCO}_{2}$ mobile phase (A), $\mathrm{pH} 2.8$, and (B) $\mathrm{CH}_{3} \mathrm{CN} / \mathrm{NH}_{4} \mathrm{HCO}_{2}(90 / 10, v / v)$ at a flow rate of $0.3 \mathrm{~mL} / \mathrm{min}$ at $25{ }^{\circ} \mathrm{C}$. The separation started with $50 \% \mathrm{~B}$ and increased up to $100 \%$ B for $10 \mathrm{~min}$, and these conditions were maintained for $1 \mathrm{~min}$. After $30 \mathrm{~s}$, the original conditions were maintained for $15 \mathrm{~min}$. 


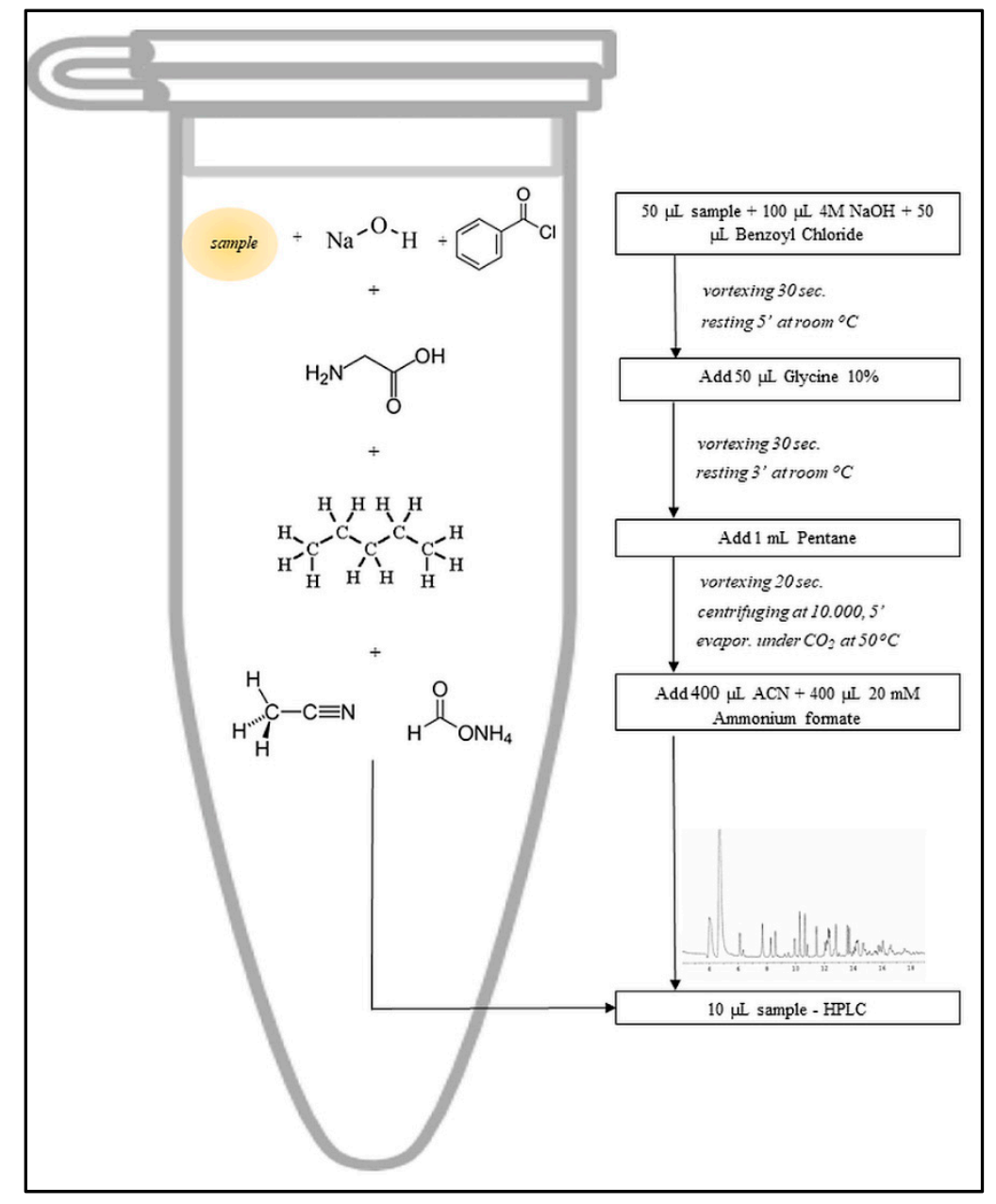

Figure 1. Samples derivatization flowchart adapted after Imbert et al. [53]. Glucose consumption was measured with an enzymatic test kit from Boehringer Mannheim-R-Biopharm. Biomass and metabolites production yields $(\mathrm{Y})$ were calculated by using the formula [38]. Y $(\mathrm{g} / \mathrm{g})=$ Product concentration $(\mathrm{g} / \mathrm{L}) /$ Initial substrate concentration $(\mathrm{g} / \mathrm{L})$.

\section{Results and Discussion}

\subsection{The Fatty Acids Profile from Processed and Unprocessed Vegetable Oil}

The profile of fatty acids content from vegetable oil before and after being processed within the kitchen was identified. The results are presented in Figure 2. The recycled kitchen oil that was subjected to transesterification contained a high amount of (9Z,12Z)-octadeca-9,12-dienoic acid (74.74\%). As can be seen from Figure 2, before being thermally processed (e.g., frying), the profile of fatty acids in vegetable oil showed an elevated concentration of (9Z)-octadecenoic acid (92.10\%). During the frying, the concentration of the major compound decreased [(9Z)-octadecenoic acid], while the content of (9Z,12Z)-octadeca-9,12-dienoic acid increased. This might have been associated with the elevated temperatures of frying ranging from 130 to $180{ }^{\circ} \mathrm{C}$, which could have facilitated the conversion of (9Z)-octadecenoic acid to (9Z,12Z)-octadeca-9,12-dienoic acid [18]. 


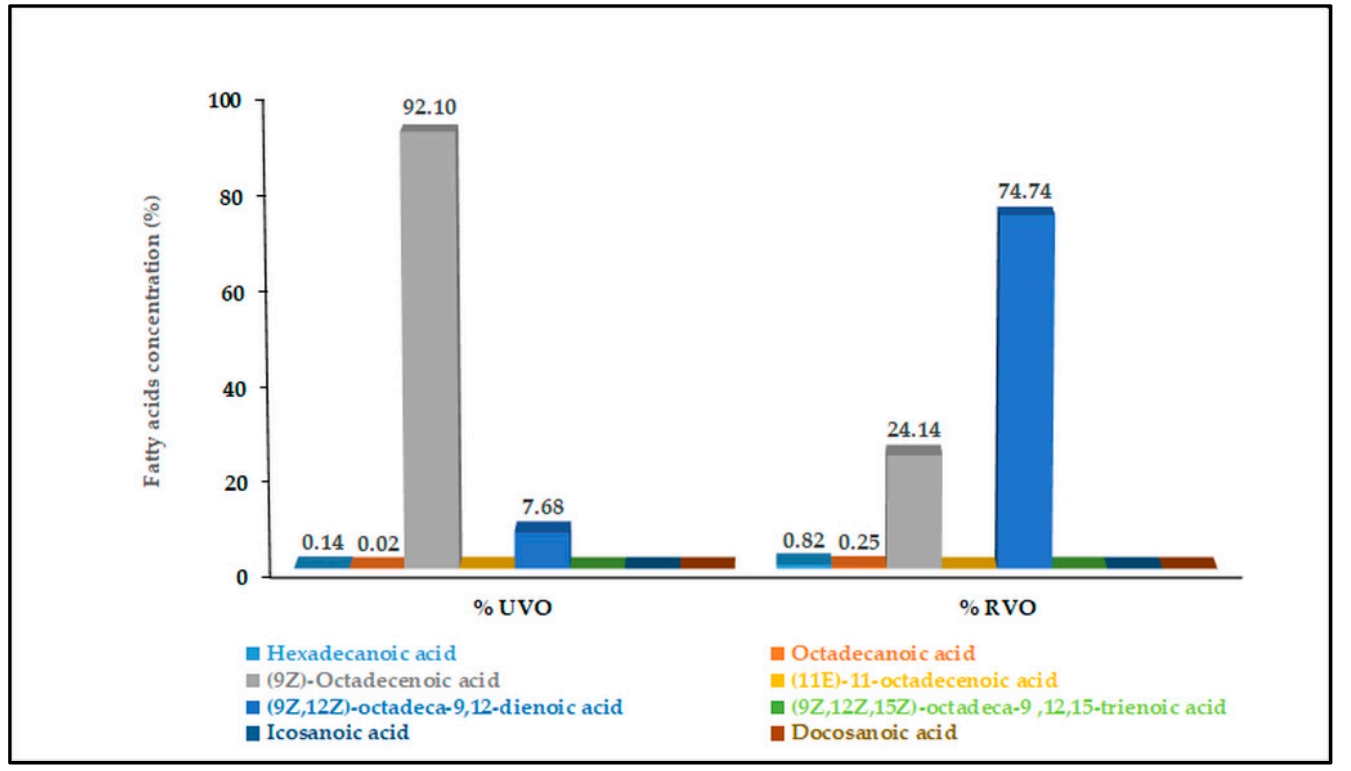

Figure 2. The fatty acids profile in vegetable oil before and after processing. UVO, unprocessed vegetable oil; RVO, recycled vegetable oil.

\subsection{Crude Glycerol Obtaining Process}

Crude glycerol was obtained from recycled kitchen oil through methanol transesterification in the presence of $\mathrm{NaOH}$ as the catalyst. The content of glycerol in the crude glycerol fraction was $30 \%$, as determined by HPLC. The crude glycerol phase appeared as a dark yellow viscous solution at room temperature $\left(23-25^{\circ} \mathrm{C}\right)$ and as a compact solidified mass at low temperatures $\left(<18^{\circ} \mathrm{C}\right)$ (Figure 3$)$.

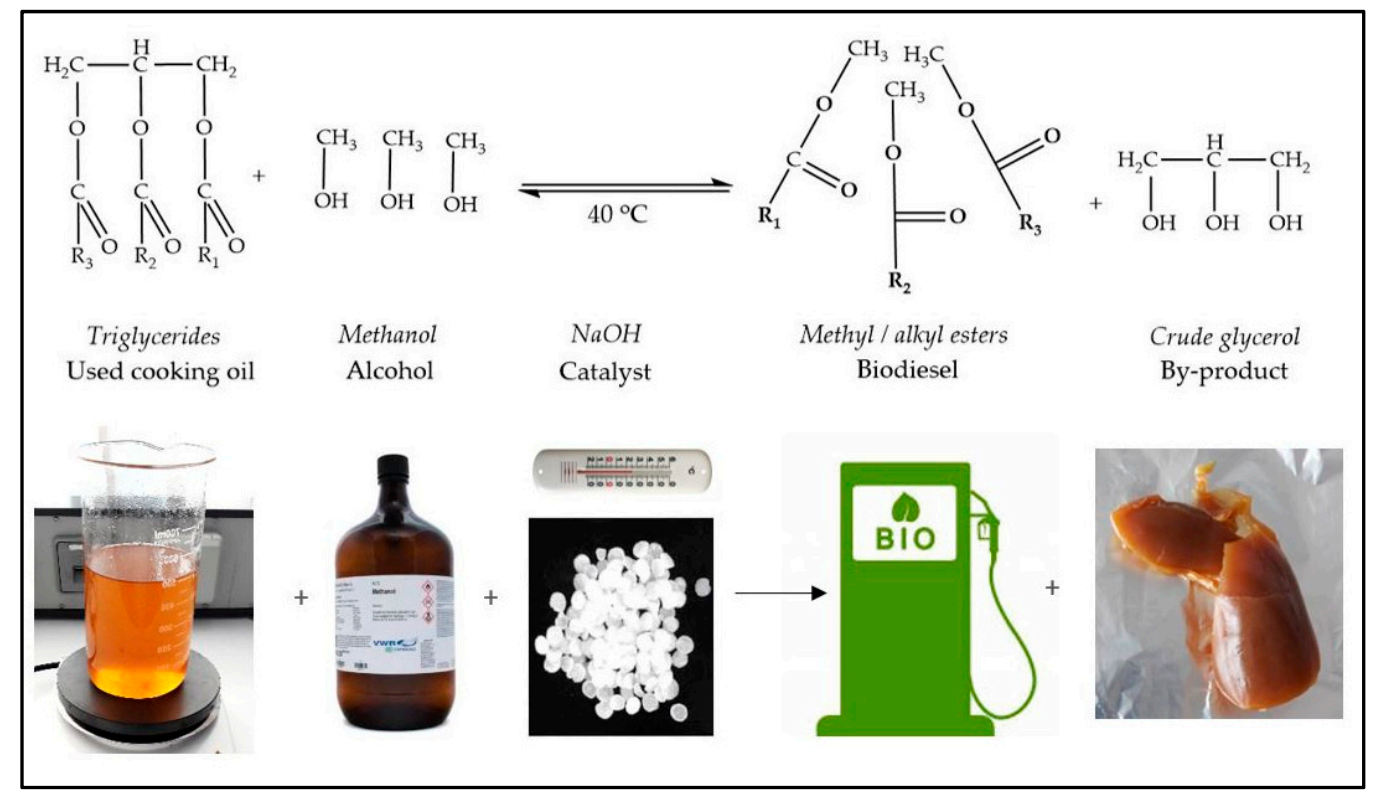

Figure 3. The crude glycerol obtaining process through transesterification.

The presence of glycerol in the crude glycerol phase was shown by FTIR spectra (Figure 4), where the functional groups associated with glycerol, $-\mathrm{OH}$ bonds, were indicated by the presence of the large peak at $3358 \mathrm{~cm}^{-1}$. Moreover, the sharp peaks shown at 2924 and $2852 \mathrm{~cm}^{-1}$ represented $\mathrm{C}-\mathrm{H}$ stretching that could be linked with the presence of polyalcohols, especially glycerol. The presence of bands at 1460 to $1436 \mathrm{~cm}^{-1}$ indicated $\mathrm{C}-\mathrm{O}-\mathrm{H}$ stretching connected with polyalcohols. The $\mathrm{C}-\mathrm{O}$ 
groups associated with the presence of glycerol were suggested by the sharp peak at $1037 \mathrm{~cm}^{-1}$. In the crude glycerol phase, different quantities of impurities such as soaps, salts, or fatty acids were present. For instance, the high-pitched peak situated at $1741 \mathrm{~cm}^{-1}$ indicated the presence of $\mathrm{C}=\mathrm{O}$ bonds specific to carboxylic acids or esters of fatty acids. The band at $1560 \mathrm{~cm}^{-1}$ showed the presence of $\mathrm{COO}^{-}$ groups particular to soaps or salts, which, in this case, may have been attributed to the catalyst involved in the transesterification reaction $[54,55]$.

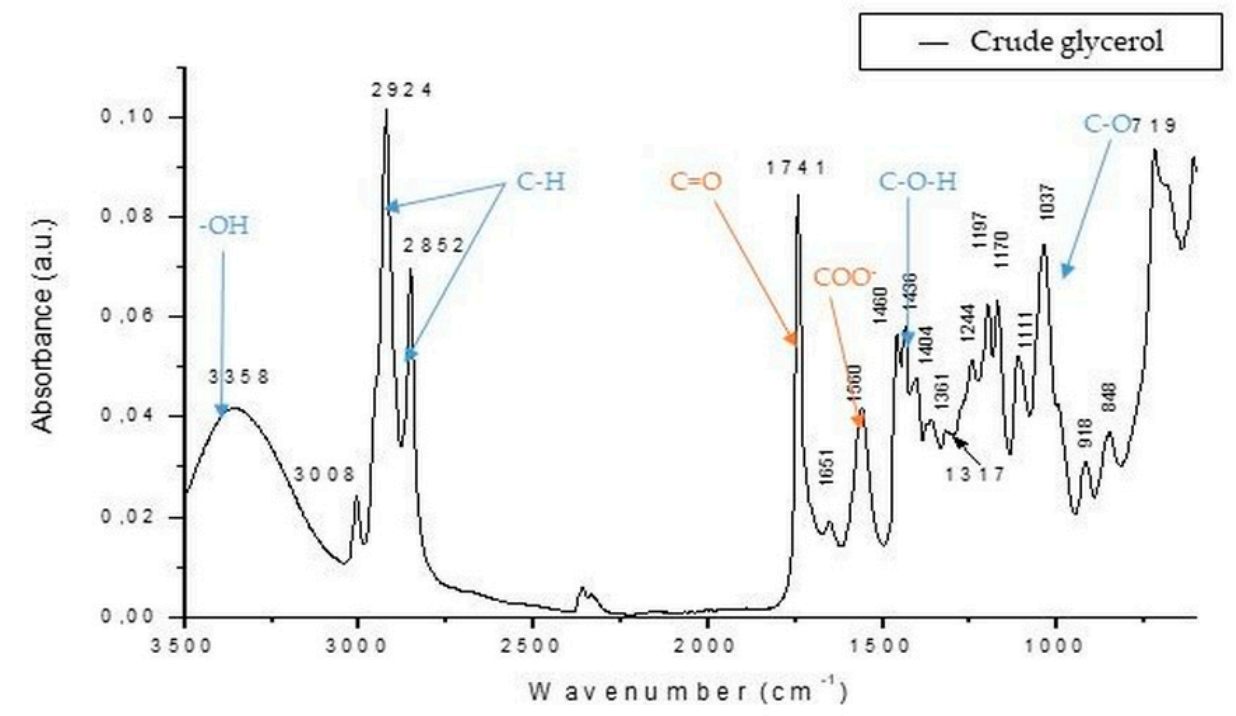

Figure 4. FTIR spectra of crude glycerol obtained from recycled kitchen oils through alkali transesterification. The blue bonds are linked with polyalcohols (glycerol) and the orange ones are associated with the impurities existing in the crude glycerol phase.

\subsection{C. zeylanoides Growth in Different Culture Media}

Numerous strains of Candida spp. have been industrially exploited for their beneficial usages in the food industry, such as C. zeylanoides, Candida etchellsii, Candida intermedia, Candida maltosa, and Candida versatilis [56]. Some of these microorganisms are well known as competent producers of organic acids, especially lactic, citric, isocitric, succinic, tartaric, or malic acids [47,57-60]. These strains are able to metabolize various sources of carbon (e.g., glycerol, glucose, fructose, galactose, mannose, mannitol, raffinose, ribose, and sucrose) [41], but some of them cannot metabolize other nutrient sources such as arabinose, cellobiose, maltose, melezitose, melibiose, rhamnose, salicin, trehalose, or xylose [42].

In this study, C. zeylanoides ATCC 20367 grew efficiently and developed full body cells in cultivation media that contained crude glycerol derived from recycled cooking oil, with the growth curves-namely viability and biomass formation-being similar to those obtained for pure glycerol or glucose as sole carbon sources. As is known from the literature [44,61], the growth of a particular yeast strain such as Candida or Yarrowia spp. is dependent on carbon concentration, nitrogen sources, aeration grade, and temperature. Moreover, when fermentation processes are conducted in stirred tank bioreactors, the mixing control plays an important role in cell growth due to the oxygen transfer rate to the fermentation broth [62]. In this context, for the present experimental work, the mixing was kept constant at $400 \mathrm{rpm}$, while a peristaltic pump was continuously bubbling filtered air $(158 \mathrm{~mL} / \mathrm{min})$ in the cultivation broth for the entire fermentation process.

Even though the glycerol content in the crude glycerol fraction was low ( $30 \%$ in this case), the yeast cells grew successfully and developed full adult bodies after $48 \mathrm{~h}$ of cultivation in inoculum medium. The yeast cells from inoculum were observed under microscope light (Figure 5). 


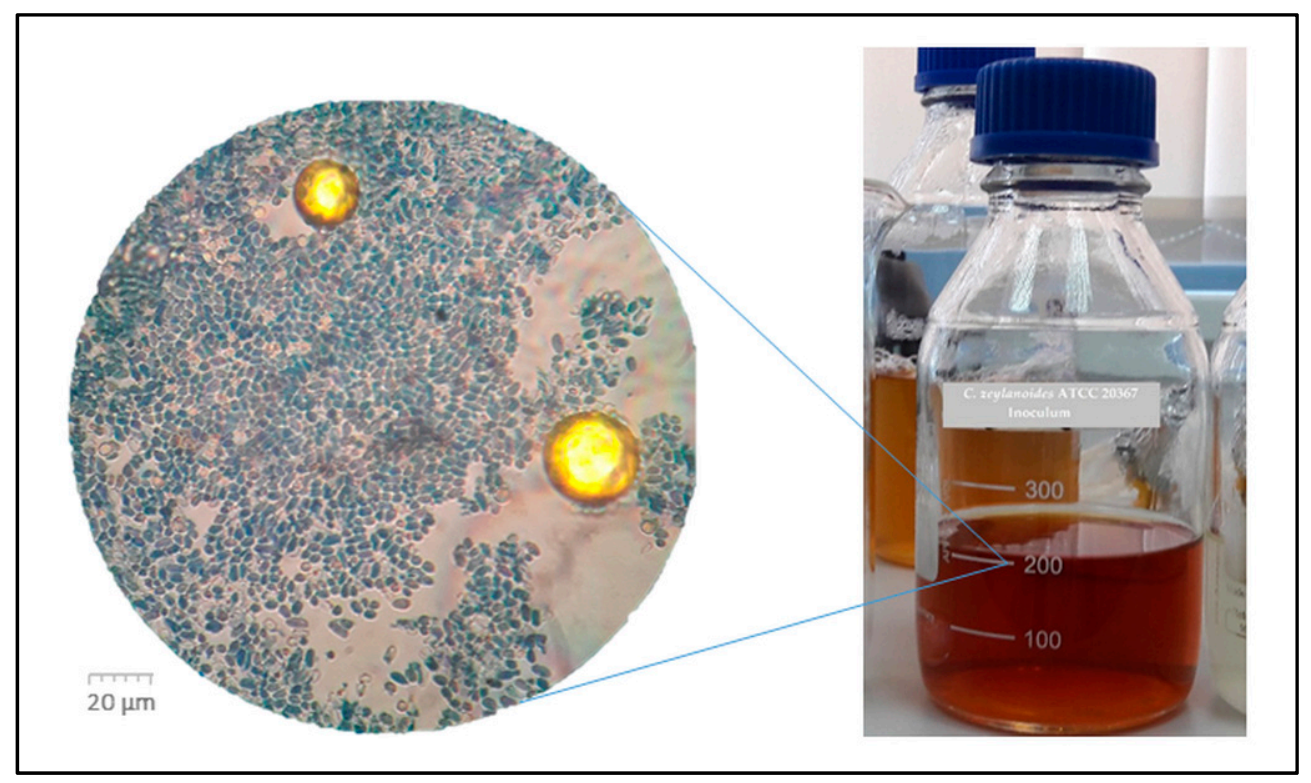

Figure 5. C. zeylanoides ATCC 20367 after $48 \mathrm{~h}$ in inoculum fermentation medium that contained crude glycerol under microscopic light. The blue stained dots represent viable cells, while the transparent shapes are the dead cells. The big yellow circles represent lipid droplets from the crude glycerol fraction.

At the moment of inoculation, the yeast cell viability in crude glycerol medium was $6.53 \pm 0.24$ $(\log 10) \mathrm{cfu} / \mathrm{mL}$. By $90 \mathrm{~h}$ of cultivation, the biomass had doubled, and the yeast viability had reached $12.86 \pm 0.62(\log 10) \mathrm{cfu} / \mathrm{mL}$. The viability and the biomass formation were not affected by the presence of possible impurities in the crude glycerol fraction. Moreover, as can be observed in Figure 6A, the cell viability and the biomass formation were similar to those obtained for pure glycerol (Figure 6B) and for glucose (Figure 6C) as main nutrient sources. In the case of yeast cells grown on crude glycerol, their viability reached the maximum point at $93 \mathrm{~h}$ of cultivation, which corresponds to complete glycerol consumption from the fermentation media.

The yeast cells viability (Figure 6A) slightly decreased until the end of the process, but the biomass quantity was still increasing after $163 \mathrm{~h}$ of cultivation. The biomass formation yield of $C$. zeylanoides ATCC 20367 on crude glycerol reached a maximum value of $0.98 \mathrm{~g} / \mathrm{g}$ after 163h, while the yields obtained for pure glycerol and glucose were $0.21 \mathrm{~g} / \mathrm{g}$ and $0.31 \mathrm{~g} / \mathrm{g}$, respectively (Table 2). The biomass formation yield of this particular strain was higher as compared with other yeast species cultivated on biodiesel derived glycerol, such as a wild type of Saccharomyces cerevisiae that has recorded a maximum yield of $0.56 \mathrm{~g}_{\text {Biomass }} / \mathrm{g}_{\text {Substrate }}$ [63]. A comparison between the C. zeylanoides ATCC 20367 growth on crude glycerol, pure glycerol, and glucose is illustrated in Figure 7. 


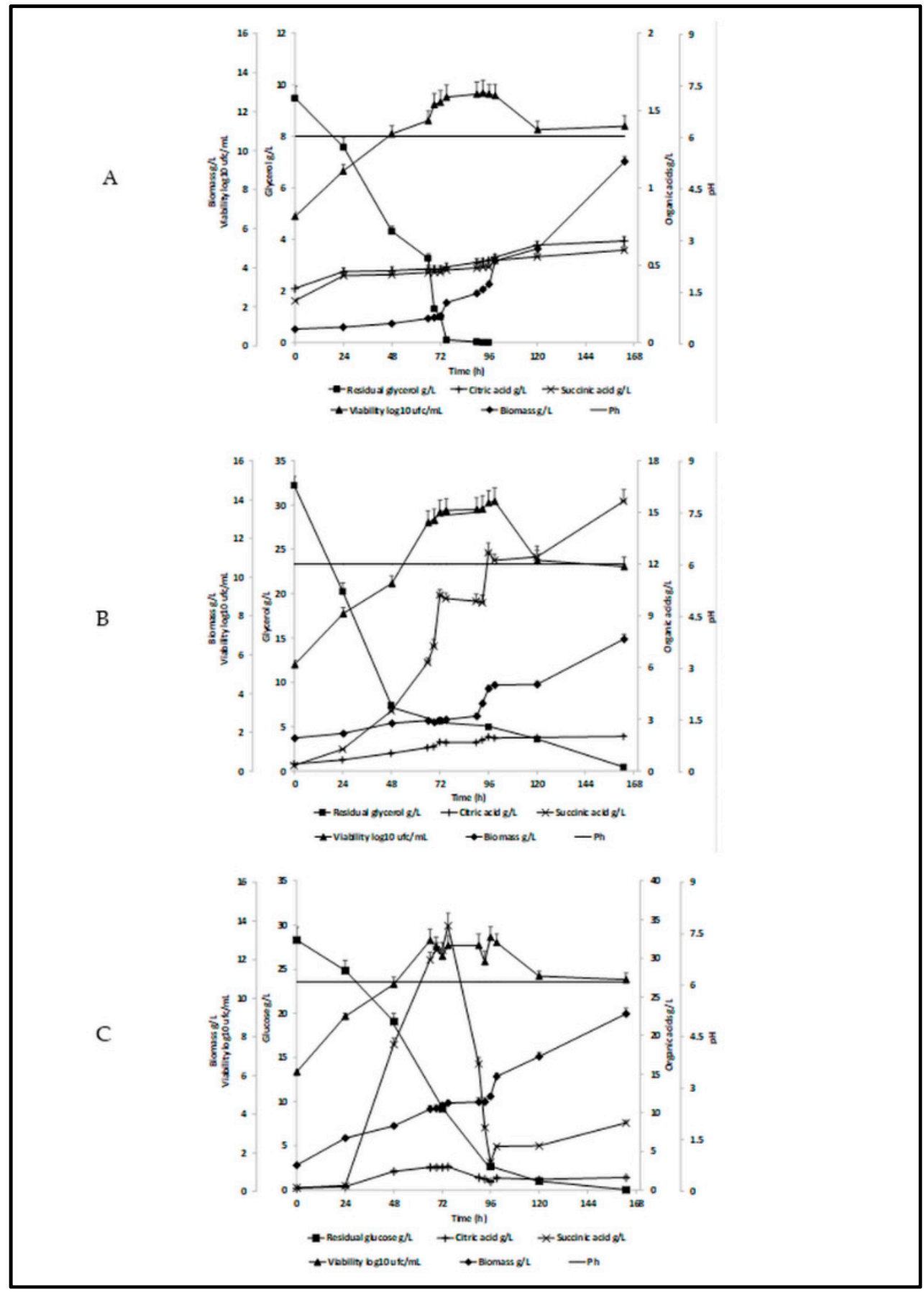

Figure 6. Yeast cell viability, biomass, $\mathrm{pH}$, organic acids (citric, succinic), and substrate consumption on different carbon sources. (A) crude glycerol; (B) pure glycerol; (C) glucose.

Table 2. The maximum yields of biomass and metabolites formation of C. zeylanoides ATCC 20367 grown on crude glycerol, pure glycerol, and glucose.

\begin{tabular}{cccc}
\hline Yield g/g & Batch CG & Batch PG & Batch Gl \\
\hline $\mathrm{Y}_{\text {Biomass }} /$ Substrate & 0.98 & 0.21 & 0.31 \\
$\mathrm{Y}_{\text {Citric acid/Substrate }}$ & 0.06 & 0.06 & 0.05 \\
$\mathrm{Y}_{\text {Succinic acid/Substrate }}$ & 0.06 & 0.48 & 1.2 \\
\hline
\end{tabular}

CG-Crude Glycerol; PG-Pure Glycerol; Gl-Glucose. 


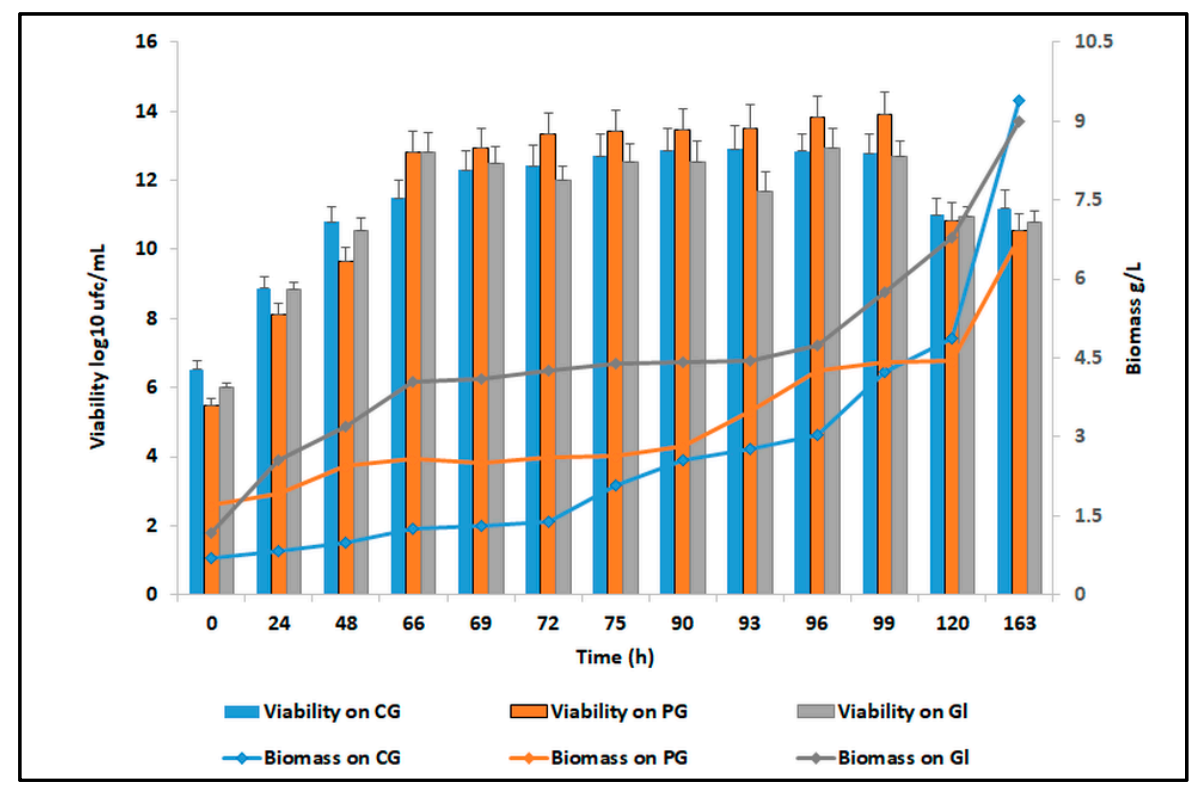

Figure 7. Comparison between the yeast cell growth (viability, biomass) on crude glycerol, pure glycerol, and glucose during $163 \mathrm{~h}$ of batch cultivation.

Considering the results registered for the biomass formation when glucose was used as a nutrient source, our results were significantly higher compared with those reported by Kamzolova and Morgunov (2017) [64], who cultivated three different species of C. zeylanoides (VKM Y-6, VKM Y-14, VKM Y-2324) on glucose. They achieved a maximum biomass concentration of $3.71 \mathrm{~g} / \mathrm{L}$ after six days of fermentation when the strain C. zeylanoides VKM Y-6 was used [64], while in our experiment, the biomass concentration exceeded $8 \mathrm{~g} / \mathrm{L}$ when C. zeylanoides ATCC 20367 was grown on glucose for almost six days (163 h) (Figure 6C).

The elevated yields for both biomass and citric acid when crude glycerol was used (Table 2) could have been attributed to the presence of fatty acids in crude glycerol fraction (Figure 4), which stimulated the enzymatic activity of the lipophilic yeast cells, generating a higher production of metabolites or biomass [65,66]. As Morgunov et al. (2013) [65] implied, the utilization of waste glycerol for the cultivation of $Y$. lipolytica strain NG40/UV7 increased the citric acid formation yield with $40.63 \%$ compared with the results obtained for pure glycerol [65].

\subsection{Succinic and Citric Acids Bio-Synthesis by C. zeylanoides ATCC 20367}

Both citric and succinic acids are small organic acids synthesized during TCA cycles by multiple microorganisms $[26,60,65,66]$ and which can be obtained from crude glycerol by using microbes such as yeast and fungal strains $[44,67,68]$. Until now, little was known about the assimilation mechanism of the crude glycerol fraction by the yeast cells and the biosynthesis of organic acids. As Morgunov and Kamzolova (2015) stated [67], the crude glycerol fraction that consists of both glycerol and different amounts of fatty acids can be metabolized either together or separately. For the synthesis of organic acids from TCA cycle (e.g., citric and succinic acids) starting from crude glycerol as the main carbon source, specific enzymes are stimulated $[65,69]$ such as glycerol kinase, isocitrate lyase, citrate synthase, aconitate hydratase, NAD- and NADP-dependent isocitrate dehydrogenases glycerol kinase, isocitrate lyase, citrate synthase, aconitate hydratase, and NAD- and NADP-dependent isocitrate dehydrogenases [67]. When glycerol or glucose is used as a nutrient source for yeast strains such as Candida or Yarrowia, many other metabolites can be synthesized (e.g., fumaric acid, pyruvic acid, $\alpha$-ketoglutaric acid, erythritol, mannitol, etc.) by stimulating/inhibiting specific enzymes or by limiting particular biogenic microelements $[64,66,69,70]$. Moreover, the organic acids bio-production, especially citric and succinic acids, is closely related to air saturation and nitrogen-limited conditions when $\mathrm{pH}$ 
values are maintained over 4.5 [44,71,72]. In the present study, the biosynthesis of organic acids (citric and succinic acids) differed considerably because of the carbon source used, as is presented in Tables 3-5. The highest values of organic acids concentrations were observed for glucose (Table 5), while the lowest quantities were observed for crude glycerol (Table 3). Our results related to citric acid concentration were close to those reported by Mirończuk et al. [70], who obtained $6.7 \pm 3.2 \mathrm{~g} / \mathrm{L}$ in flask-shake cultivation and $1.4 \pm 0.42 \mathrm{~g} / \mathrm{L}$ at the batch bioreactor level by using different strains of Y. lipolytica on pure glycerol-containing media. The differences between the organic acids production when glycerol or glucose is used might be due to the fact that yeast strains such as Candida or Rhodosporidium [39,42] are glucophilic strains. The metabolism of glycerol versus glucose involves a different enzymatic package, which leads to the formation of organic acids [39,71].

Table 3. Results obtained for C. zeylanoides ATCC 20367 grown on crude glycerol at $\mathrm{pH}$ 6. The shown data represent the mean values of three biological replicates, and the standard deviation $( \pm)$ is under $5 \%$.

\begin{tabular}{cccccc}
\hline Time (h) & $\begin{array}{c}\text { Viability } \\
\text { Log10 ufc/mL }\end{array}$ & Biomass g/L & Citric Acid g/L & Succinic Acid g/L & $\begin{array}{c}\text { Residual } \\
\text { Glycerol g/L }\end{array}$ \\
\hline 0 & $6.53 \pm 0.24$ & $0.7 \pm 0.02$ & $0.35 \pm 0.01$ & $0.28 \pm 0.00$ & $9.48 \pm 0.45$ \\
24 & $8.88 \pm 0.34$ & $0.82 \pm 0.04$ & $0.46 \pm 0.02$ & $0.43 \pm 0.01$ & $7.57 \pm 0.37$ \\
48 & $10.80 \pm 0.42$ & $0.99 \pm 0.05$ & $0.47 \pm 0.02$ & $0.44 \pm 0.02$ & $4.31 \pm 0.21$ \\
66 & $11.48 \pm 0.51$ & $1.25 \pm 0.03$ & $0.47 \pm 0.02$ & $0.45 \pm 0.02$ & $3.28 \pm 0.16$ \\
69 & $12.30 \pm 0.56$ & $1.31 \pm 0.04$ & $0.47 \pm 0.00$ & $0.45 \pm 0.02$ & $1.30 \pm 0.05$ \\
72 & $12.41 \pm 0.62$ & $1.40 \pm 0.02$ & $0.47 \pm 0.01$ & $0.46 \pm 0.01$ & $1.00 \pm 0.05$ \\
75 & $12.70 \pm 0.62$ & $2.07 \pm 0.01$ & $0.49 \pm 0.02$ & $0.47 \pm 0.01$ & $0.10 \pm 0.00$ \\
90 & $12.86 \pm 0.62$ & $2.56 \pm 0.11$ & $0.52 \pm 0.02$ & $0.48 \pm 0.02$ & $0.02 \pm 0.00$ \\
93 & $12.90 \pm 0.66$ & $2.76 \pm 0.10$ & $0.52 \pm 0.01$ & $0.48 \pm 0.02$ & $0.00 \pm 0.00$ \\
96 & $12.84 \pm 0.51$ & $3.03 \pm 0.15$ & $0.53 \pm 0.00$ & $0.49 \pm 0.02$ & - \\
99 & $12.77 \pm 0.57$ & $4.24 \pm 0.13$ & $0.55 \pm 0.02$ & $0.53 \pm 0.02$ & - \\
120 & $11.00 \pm 0.46$ & $4.86 \pm 0.15$ & $0.63 \pm 0.02$ & $0.55 \pm 0.02$ & - \\
163 & $11.18 \pm 0.55$ & $9.38 \pm 0.26$ & $0.66 \pm 0.02$ & $0.60 \pm 0.02$ & - \\
\hline
\end{tabular}

Table 4. Results obtained for C. zeylanoides ATCC 20367 grown on pure glycerol at $\mathrm{pH}$ 6. The shown data represent the mean values of three biological replicates, and the standard deviation $( \pm)$ is under 5\%.

\begin{tabular}{cccccc}
\hline Time (h) & $\begin{array}{c}\text { Viability } \\
\text { Log10 ufc/mL }\end{array}$ & Biomass g/L & Citric Acid g/L & Succinic Acid g/L & $\begin{array}{c}\text { Residual } \\
\text { Glycerol g/L }\end{array}$ \\
\hline 0 & $5.48 \pm 0.21$ & $1.70 \pm 0.02$ & $0.41 \pm 0.02$ & $0.33 \pm 0.01$ & $32.22 \pm 1.01$ \\
24 & $8.11 \pm 0.31$ & $1.93 \pm 0.05$ & $0.65 \pm 0.02$ & $1.27 \pm 0.02$ & $20.22 \pm 1.00$ \\
48 & $9.67 \pm 0.40$ & $2.45 \pm 0.10$ & $1.02 \pm 0.03$ & $3.48 \pm 0.10$ & $7.42 \pm 0.35$ \\
66 & $12.83 \pm 0.58$ & $2.58 \pm 0.11$ & $1.34 \pm 0.05$ & $6.31 \pm 0.23$ & - \\
69 & $12.92 \pm 0.58$ & $2.5 \pm 0.12$ & $1.40 \pm 0.06$ & $7.23 \pm 0.38$ & - \\
72 & $13.32 \pm 0.62$ & $2.62 \pm 0.12$ & $1.66 \pm 0.03$ & $10.20 \pm 0.33$ & $5.60 \pm 0.27$ \\
75 & $13.42 \pm 0.62$ & $2.65 \pm 0.12$ & $1.66 \pm 0.03$ & $9.99 \pm 0.32$ & - \\
90 & $13.48 \pm 0.61$ & $2.83 \pm 0.13$ & $1.64 \pm 0.05$ & $9.83 \pm 0.44$ & - \\
93 & $13.52 \pm 0.66$ & $3.48 \pm 0.13$ & $1.79 \pm 0.06$ & $9.75 \pm 0.45$ & - \\
96 & $13.82 \pm 0.62$ & $4.25 \pm 0.14$ & $1.96 \pm 0.07$ & $12.66 \pm 0.56$ & $5.01 \pm 0.22$ \\
99 & $13.91 \pm 0.66$ & $4.43 \pm 0.11$ & $1.93 \pm 0.05$ & $12.22 \pm 0.35$ & - \\
120 & $10.84 \pm 0.52$ & $4.46 \pm 0.15$ & $1.95 \pm 0.06$ & $12.43 \pm 0.61$ & $3.61 \pm 0.17$ \\
163 & $10.54 \pm 0.48$ & $6.80 \pm 0.24$ & $2.00 \pm 0.07$ & $15.66 \pm 0.66$ & $0.45 \pm 0.01$ \\
\hline
\end{tabular}


Table 5. Results obtained for C. zeylanoides ATCC 20367 grown on glucose at $\mathrm{pH} 6$. The shown data represent the mean values of three biological replicates, and the standard deviation $( \pm)$ is under $5 \%$.

\begin{tabular}{cccccc}
\hline Time (h) & $\begin{array}{c}\text { Viability } \\
\text { Log10 ufc/mL }\end{array}$ & Biomass g/L & Citric Acid g/L & Succinic Acid g/L & $\begin{array}{c}\text { Residual } \\
\text { Glucose g/L }\end{array}$ \\
\hline 0 & $6.00 \pm 0.11$ & $1.17 \pm 0.02$ & $0.23 \pm 0.01$ & $0.28 \pm 0.00$ & $28.35 \pm 1.41$ \\
24 & $8.86 \pm 0.17$ & $2.57 \pm 0.11$ & $0.45 \pm 0.01$ & $0.59 \pm 0.02$ & $24.84 \pm 1.18$ \\
48 & $10.53 \pm 0.37$ & $3.19 \pm 0.12$ & $2.41 \pm 0.09$ & $18.81 \pm 0.80$ & $19.06 \pm 0.92$ \\
66 & $12.80 \pm 0.58$ & $4.06 \pm 0.20$ & $2.92 \pm 0.10$ & $29.76 \pm 1.00$ & - \\
69 & $12.49 \pm 0.49$ & $4.09 \pm 0.20$ & $2.94 \pm 0.12$ & $31.02 \pm 1.02$ & - \\
72 & $12.00 \pm 0.42$ & $4.25 \pm 0.12$ & $2.94 \pm 0.14$ & $31.03 \pm 1.00$ & $9.22 \pm 0.32$ \\
75 & $12.53 \pm 0.53$ & $4.39 \pm 0.11$ & $3.01 \pm 0.15$ & $34.24 \pm 1.52$ & - \\
90 & $12.53 \pm 0.61$ & $4.43 \pm 0.22$ & $1.59 \pm 0.06$ & $16.36 \pm 0.80$ & - \\
93 & $11.70 \pm 0.55$ & $4.44 \pm 0.20$ & $1.42 \pm 0.02$ & $8.09 \pm 0.20$ & - \\
96 & $12.95 \pm 0.56$ & $4.74 \pm 0.11$ & $1.07 \pm 0.04$ & $3.62 \pm 0.10$ & $2.66 \pm 0.10$ \\
99 & $12.69 \pm 0.44$ & $5.76 \pm 0.19$ & $1.57 \pm 0.04$ & $5.67 \pm 0.11$ & - \\
120 & $10.95 \pm 0.27$ & $6.80 \pm 0.20$ & $1.37 \pm 0.05$ & $5.71 \pm 0.15$ & $1.01 \pm 0.02$ \\
163 & $10.77 \pm 0.33$ & $9.00 \pm 0.29$ & $1.63 \pm 0.07$ & $8.71 \pm 0.28$ & $0.04 \pm 0.00$ \\
\hline
\end{tabular}

The low content of glycerol in the crude glycerol fraction impacted the organic acids production by C. zeylanoides (Table 3).

Succinic acid is one of the organic acids with a major role as a monomer for the production of a number of polymers [73]. It is mostly bio-synthesized at high concentrations by different microorganisms from glucidic substrates such as glucose, fructose, lactose, maltose, etc. [73]. Even though the main carbon source is glycerol or glucose, the succinic acid biosynthesis by yeast strains such as Candida and Yarrowia is limited by the oxygen present in the culture medium, because a specific enzyme such as succinate dehydratase catalyzes the oxidation of succinate to fumarate [72]. Cultivated on pure glycerol, C. zeylanoides biosynthesized up to $15.66 \mathrm{~g} / \mathrm{L}$ of succinic acid after $163 \mathrm{~h}$ of cultivation (Table 4). In our case, for the succinic acid biosynthesis by C. zeylanoides ATCC 20367, glucose was the appropriate substrate for increased concentrations production (Table 5) in a time interval of $75 \mathrm{~h}$. After this interval, the succinic acid production abruptly decreased until the end of the process, a fact that could be explained by its conversion to other intermediates of the TCA cycle, organic acids such as fumaric, malic, or $\alpha$-ketoglutaric acids [73,74]. Compared with literature, our results after $75 \mathrm{~h}$ of cultivating C. zeylanoides ATCC 20367 on media containing glucose were comparable with those achieved by Yuzbashev et al. [75], who cultivated a genetically engineered strain of Y. lipolytica on a mixture of glucose and glycerol. They obtained a maximum concentration of $45 \mathrm{~g} / \mathrm{L}$ succinic acid after $168 \mathrm{~h}$ using shake flask fermentation [75].

In order to emphasize to the industry sector the terms of costs and the economic feasibility, we strongly recommend, considering the present findings, the co-production of biodiesel and valuable compounds such as citric and succinic acids in the one-pot synthesis process. Therefore, it is expected that biodiesel industries may better direct their by-product (crude glycerol), thus avoiding a growing environmental problem and providing an extra source of income.

\section{Conclusions}

Recycled kitchen oils are a cheap source of reusable biomass for the manufacturing of renewable biofuels such as biodiesel. The crude glycerol fraction that remains after transesterification constitutes a valuable nutrient source for microorganisms such as $C$. zeylanoides. In this study, C. zeylanoides ATCC 20367 was cultivated for $163 \mathrm{~h}$ on a crude glycerol-containing medium with a low content of glycerol, and its viability was maintained at high values until the glycerol content was depleted after $93 \mathrm{~h}$. Candida's viability and biomass formation rate were similar to those achieved for batch fermentations with pure glycerol or glucose as a single carbon source. In cultivation media containing crude glycerol, due to the lower quantity of glycerol, C. zeylanoides ATCC 20367 produced lower amounts of citric and succinic acids as compared with pure glycerol and glucose. The fact that this particular strain grows 
efficiently on lipophilic substrates such as raw glycerol derived from biodiesel represents a promising perspective for future investigations of crude glycerol fractions in order to obtain valuable chemicals (e.g., organic acids) with high yields.

The results presented within this paper contribute to the scientific background by highlighting the importance of some investigated parameters, such as viability. The elevated viability of the $C$. zeylanoides cells when it was cultivated on crude glycerol indicated that this particular strain is flexible and adapts its metabolism to the growing environment, leading to a step forward for future studies of yeast metabolism and their potential to synthesize valuable compounds. Moreover, the viability results from this research contribute to the fundamental academic research considering the utilization of yeast strains in biotechnological processes.

Author Contributions: L.M. and D.C.V. designed and conducted the experiment in the laboratory. L.M. and F.R. performed the derivatization process and HPLC analysis. L.M. and F.F. performed the FTIR analysis and data interpretation. F.V.D. analyzed the fatty acids content. L.M. and D.C.V. assembled the manuscript. M.T. and A.R. reviewed and outlined the first draft of the manuscript. All authors read and approved the final version of the manuscript.

Funding: This work was supported by the ProGlyCom project, developed with the support of ANCSI (POC/ID P_37_637, 2016-2020).

Acknowledgments: The authors would like to thank to Vasile Coman for fruitful discussions and for the linguistic review.

Conflicts of Interest: The authors declare no conflict of interest. The funders had no role in the design of the study; in the collection, analyses, or interpretation of data; in the writing of the manuscript, or in the decision to publish the results.

\section{References}

1. Yusuf, N.N.A.N.; Kamarudin, S.K.; Yaakub, Z. Overview on the current trends in biodiesel production. Energy Convers. Manag. 2011, 52, 2741-2751. [CrossRef]

2. Srivastava, N.; Rathour, R.; Jha, S.; Pandey, K.; Srivastava, M.; Thakur, V.K.; Sengar, S.; Gupta, V.; Mazumder, P.; Khan, A.; et al. Microbial Beta Glucosidase Enzymes: Recent Advances in Biomass Conversation for Biofuels Application. Biomolecules 2019, 9, 23. [CrossRef] [PubMed]

3. Demirbaş, A. Biodiesel fuels from vegetable oils via catalytic and non-catalytic supercritical alcohol transesterifications and other methods: A survey. Energy Convers. Manag. 2003, 44, 2093-2109. [CrossRef]

4. Lotero, E.; Liu, Y.; Lopez, D.E.; Suwannakarn, K.; Bruce, D.A.; Goodwin, J.G. Synthesis of Biodiesel via Acid Catalysis. Ind. Eng. Chem. Res. 2005, 44, 5353-5363. [CrossRef]

5. Vodnar, D.C.; Dulf, F.V.; Pop, O.L.; Socaciu, C. L (+)-lactic acid production by pellet-form Rhizopus oryzae NRRL 395 on biodiesel crude glycerol. Microb. Cell Factories 2013, 12. [CrossRef] [PubMed]

6. EU Biofuels Annual. 2018. Available online: https://gain.fas.usda.gov (accessed on 13 June 2019).

7. Biofuel Mandates in the EU by Member State in 2018. Available online: https://gain.fas.usda.gov (accessed on 13 June 2019).

8. Bezergianni, S.; Dimitriadis, A. Comparison between different types of renewable diesel. Renew. Sustain. Energy Rev. 2013, 21, 110-116. [CrossRef]

9. Kulkarni, M.G.; Dalai, A.K. Waste Cooking OilAn Economical Source for Biodiesel: A Review. Ind. Eng. Chem. Res. 2006, 45, 2901-2913. [CrossRef]

10. Kim, K.H.; Lee, O.K.; Lee, E.Y. Nano-Immobilized Biocatalysts for Biodiesel Production from Renewable and Sustainable Resources. Catalysts 2018, 8, 68. [CrossRef]

11. Demirbaş, A. Biomass resource facilities and biomass conversion processing for fuels and chemicals. Energy Convers. Manag. 2001, 42, 1357-1378. [CrossRef]

12. Călinoiu, L.F.; Vodnar, D.C. Whole Grains and Phenolic Acids: A Review on Bioactivity, Functionality, Health Benefits and Bioavailability. Nutrients 2018, 10. [CrossRef]

13. Călinoiu, L.-F.; Mitrea, L.; Precup, G.; Bindea, M.; Rusu, B.; Dulf, F.-V.; Ștefănescu, B.-E.; Vodnar, D.-C. Characterization of Grape and Apple Peel Wastes' Bioactive Compounds and Their Increased Bioavailability After Exposure to Thermal Process. Bull. Univ. Agric. Sci. Vet. Med. Cluj-Napoca-Food Sci. Technol. 2017, 74, 80-89. [CrossRef] 
14. Teleky, B.E.; Vodnar, D.C. Biomass-Derived Production of Itaconic Acid as a Building Block in Specialty Polymers. Polymers 2019, 11, 27. [CrossRef] [PubMed]

15. Vodnar, D.C.; Călinoiu, L.F.; Dulf, F.V.; Ștefănescu, B.E.; Crișan, G.; Socaciu, C. Identification of the bioactive compounds and antioxidant, antimutagenic and antimicrobial activities of thermally processed agro-industrial waste. Food Chem. 2017, 231, 131-140. [CrossRef] [PubMed]

16. Szabo, K.; Cătoi, A.-F.; Vodnar, D.C. Bioactive Compounds Extracted from Tomato Processing by-Products as a Source of Valuable Nutrients. Plant Foods Hum. Nutr. 2018, 73, 268-277. [CrossRef] [PubMed]

17. Tran, N.N.; Tišma, M.; Budžaki, S.; McMurchie, E.J.; Gonzalez, O.M.M.; Hessel, V.; Ngothai, Y. Scale-up and economic analysis of biodiesel production from recycled grease trap waste. Appl. Energy 2018, 229, 142-150. [CrossRef]

18. Chhetri, A.B.; Watts, K.C.; Islam, M.R. Waste Cooking Oil as an Alternate Feedstock for Biodiesel Production. Energies 2008, 1, 3-18. [CrossRef]

19. Wang, X.-L.; Zhou, J.-J.; Sun, Y.-Q.; Xiu, Z.-L. Bioconversion of Raw Glycerol From Waste Cooking-Oil-Based Biodiesel Production to 1,3-Propanediol and Lactate by a Microbial Consortium. Front. Bioeng. Biotechnol. 2019, 7. [CrossRef] [PubMed]

20. Ataya, F.; Dubé, M.A.; Ternan, M. Acid-Catalyzed Transesterification of Canola Oil to Biodiesel under Singleand Two-Phase Reaction Conditions. Energy Fuels 2007, 21, 2450-2459. [CrossRef]

21. Patrascoiu, M.; Rathbauer, J.; Negrea, M.; Zeller, R. Perspectives of safflower oil as biodiesel source for South Eastern Europe (comparative study: Safflower, soybean and rapeseed). Fuel 2013, 111, 114-119. [CrossRef]

22. Jindapon, W.; Ngamcharussrivichai, C. Heterogeneously catalyzed transesterification of palm oil with methanol to produce biodiesel over calcined dolomite: The role of magnesium oxide. Energy Convers. Manag. 2018, 171, 1311-1321. [CrossRef]

23. Ortega-de la Rosa, N.D.; Vazquez-Vazquez, J.L.; Huerta-Ochoa, S.; Gimeno, M.; Gutierrez-Rojas, M. Stable bioemulsifiers are produced by Acinetobacter bouvetii UAM25 growing in different carbon sources. Bioprocess Biosyst. Eng. 2018, 41, 859-869. [CrossRef] [PubMed]

24. Gutiérrez-Ortega, N.; Ramos-Ramírez, E.; Serafín-Muñoz, A.; Zamorategui-Molina, A.; Monjaraz-Vallej, J. Use of $\mathrm{Co} / \mathrm{Fe}-\mathrm{Mixed}$ Oxides as Heterogeneous Catalysts in Obtaining Biodiesel. Catalysts 2019. [CrossRef]

25. Kong, P.S.; Aroua, M.K.; Wan Daud, W.M.A. Conversion of crude and pure glycerol into derivatives. A feasibility evaluation. Renew. Sustain. Energy Rev. 2016, 63, 533-555. [CrossRef]

26. Mitrea, L.; Trif, M.; Cătoi, A.F.; Vodnar, D.C. Utilization of biodiesel derived-glycerol for 1,3-PD and citric acid production. Microb. Cell Fact. 2017, 16, 190. [CrossRef] [PubMed]

27. Ben Hassen Trabelsi, A.; Zaafouri, K.; Baghdadi, W.; Naoui, S.; Ouerghi, A. Second generation biofuels production from waste cooking oil via pyrolysis process. Renew. Energy 2018, 126, 888-896. [CrossRef]

28. Gerpen, J.V. Biodiesel processing and production. Fuel Process. Technol. 2005, 86, 1097-1107. [CrossRef]

29. Arumugam, A.; Ponnusami, V. Production of biodiesel by enzymatic transesterification of waste sardine oil and evaluation of its engine performance. Heliyon 2017, 3, e00486. [CrossRef]

30. Mitrea, L.; Călinoiu, L.-F.; Precup, G.; Bindea, M.; Rusu, B.; Trif, M.; Ștefănescu, B.-E.; Pop, I.-D.; Vodnar, D.-C. Isolated Microorganisms for Bioconversion of Biodiesel-Derived Glycerol Into 1,3-Propanediol. Bull. Univ. Agric. Sci. Vet. Med. Cluj-Napoca-Food Sci. Technol. 2017, 74, 43-49. [CrossRef]

31. Busic, A.; Kundas, S.; Morzak, G.; Belskaya, H.; Mardetko, N.; Ivancic Santek, M.; Komes, D.; Novak, S.; Santek, B. Recent Trends in Biodiesel and Biogas Production. Food Technol. Biotechnol. 2018, 56, $152-173$. [CrossRef]

32. Zhou, J.-J.; Shen, J.-T.; Wang, X.-L.; Sun, Y.-Q.; Xiu, Z.-L. Stability and oscillatory behavior of microbial consortium in continuous conversion of crude glycerol to 1,3-propanediol. Appl. Microbiol. Biotechnol. 2018, 102, 8291-8305. [CrossRef]

33. Luo, X.; Ge, X.; Cui, S.; Li, Y. Value-added processing of crude glycerol into chemicals and polymers. Bioresour. Technol. 2016, 215, 144-154. [CrossRef] [PubMed]

34. Bindea, M.; Rusu, B.; Rusu, A.; Trif, M.; Leopold, L.F.; Dulf, F.; Vodnar, D.C. Valorification of crude glycerol for pure fractions of docosahexaenoic acid and beta-carotene production by using Schizochytrium limacinum and Blakeslea trispora. Microb. Cell Factories 2018, 17. [CrossRef]

35. Ma, J.S.; Jiang, H.; Hector, S.B.; Xiao, Z.H.; Li, J.L.; Liu, R.K.; Li, C.Z.; Zeng, B.Q.; Liu, G.Q.; Zhu, Y.H. Adaptability of Klebsiella pneumoniae 2e, a Newly Isolated 1,3-Propanediol-Producing Strain, to Crude Glycerol as Revealed by Genomic Profiling. Appl. Env. Microbiol. 2019, 85, 15. [CrossRef] [PubMed] 
36. Oh, B.-R.; Lee, S.-M.; Heo, S.-Y.; Seo, J.-W.; Kim, C.H. Efficient production of 1,3-propanediol from crude glycerol by repeated fed-batch fermentation strategy of a lactate and 2,3-butanediol deficient mutant of Klebsiella pneumoniae. Microb. Cell Factories 2018, 17. [CrossRef] [PubMed]

37. Samudrala, S.P.; Bhattacharya, S. Toward the Sustainable Synthesis of Propanols from Renewable Glycerol over MoO3-Al2O3 Supported Palladium Catalysts. Catalysts 2018, 8. [CrossRef]

38. Dolejš, I.; Líšková, M.; Krasňan, V.; Markošová, K.; Rosenberg, M.; Lorenzini, F.; Marr, A.C.; Rebroš, M. Production of 1,3-Propanediol from Pure and Crude Glycerol Using Immobilized Clostridium butyricum. Catalysts 2019, 9, 13. [CrossRef]

39. Nasirian, N.; Mirzaie, M.; Cicek, N.; Levin, D.B. Lipid and carotenoid synthesis by Rhodosporidium diobovatum, grown on glucose versus glycerol, and its biodiesel properties. Can. J. Microbiol. 2018, 64, 277-289. [CrossRef]

40. Athenaki, M.; Gardeli, C.; Diamantopoulou, P.; Tchakouteu, S.S.; Sarris, D.; Philippoussis, A.; Papanikolaou, S. Lipids from yeasts and fungi: Physiology, production and analytical considerations. J. Appl. Microbiol. 2018, 124, 336-367. [CrossRef]

41. Anastassiadis, S.G.; Rehm, H.-J. Oxygen and temperature effect on continuous citric acid secretion in Candida oleophila. Electron. J. Biotechnol. 2006, 9. [CrossRef]

42. Khan, A.; Bhide, A.; Gadre, R. Mannitol production from glycerol by resting cells of Candida magnoliae. Bioresour. Technol. 2009, 100, 4911-4913. [CrossRef]

43. Cavallo, E.; Charreau, H.; Cerrutti, P.; Laura Foresti, M. Yarrowia lipolytica: A model yeast for citric acid production. Fems. Yeast Res. 2017, 17. [CrossRef] [PubMed]

44. Rywińska, A.; Juszczyk, P.; Wojtatowicz, M.; Robak, M.; Lazar, Z.; Tomaszewska, L.; Rymowicz, W. Glycerol as a promising substrate for Yarrowia lipolytica biotechnological applications. Biomass Bioenergy 2013, 48, 148-166. [CrossRef]

45. Xiaoyan, L.; Yu, X.; Lv, J.; Xu, J.; Xia, J.; Wu, Z.; Zhang, T.; Deng, Y. A cost-effective process for the coproduction of erythritol and lipase with Yarrowia lipolytica M53 from waste cooking oil. Food Bioprod. Process. 2017, 103, 86-94. [CrossRef]

46. Wen, Z.; Bachmann, C.; Grisso, R.; Arogo, J.; Vaughan, D. Making Your Own Biodiesel. 2015. Available online: https://www.researchgate.net/publication/268397302_Making_Your_Own_Biodiesel (accesed on 17 January 2019).

47. Takayama, K.; Adachi, T.; Kohata, M.; Hattori, K.; Tomiyama, T. Biotechnical citric acid prepn.-by cultivating yeast mutants having larger iron ion requirements. U.S. Patent US3926724A, 25 March 2019.

48. Christie, W.W. Preparation of Methyl Ester and Other Derivatives, 1st ed.; Oily Press: Glasgow, UK, 1989.

49. Dulf, F.V.; Vodnar, D.C.; Dulf, E.H.; Pintea, A. Phenolic compounds, flavonoids, lipids and antioxidant potential of apricot (Prunus armeniaca L.) pomace fermented by two filamentous fungal strains in solid state system. Chem. Cent. J. 2017, 11, 92. [CrossRef] [PubMed]

50. Dulf, F.V.; Vodnar, D.C.; Dulf, E.-H.; Diaconeasa, Z.; Socaciu, C. Liberation and recovery of phenolic antioxidants and lipids in chokeberry (Aronia melanocarpa) pomace by solid-state bioprocessing using Aspergillus niger and Rhizopus oligosporus strains. LWT 2018, 87, 241-249. [CrossRef]

51. Ziegler, N.R.; Halvorson, H.O. Application of Statistics to Problems in Bacteriology: IV. Experimental Comparison of the Dilution Method, the Plate Count, and the Direct Count for the Determination of Bacterial Populations. J. Bacteriol. 1935, 29, 609-634. [PubMed]

52. Prakash, M. Methylene Blue Staining. Available online: https://www.protocols.io/view/Methylene-Bluestaining-fd7bi9n (accessed on 13 March 2019).

53. Imbert, L.; Saussereau, E.; Lacroix, C. Analysis of Eight Glycols in Serum Using LC-ESI-MS-MS. J. Anal. Toxicol. 2014, 38, 676-680. [CrossRef]

54. Kongjao, S.; Somsak, D.; Mali, H. Purification of crude glycerol derived from waste used-oil methyl ester plant. Korean J. Chem. Eng. 2010, 27, 944-949. [CrossRef]

55. Kowalski, M.; Kowalska, K.; Wiszniowski, J.; Turek-Szytow, J. Qualitative analysis of activated sludge using FT-IR technique. Chem. Zvesti 2018, 72, 2699-2706. [CrossRef]

56. Bourdichon, F.; Casaregola, S.; Farrokh, C.; Frisvad, J.C.; Gerds, M.L.; Hammes, W.P.; Harnett, J.; Huys, G.; Laulund, S.; Ouwehand, A.; et al. Food fermentations: Microorganisms with technological beneficial use. Int. J. Food Microbiol. 2012, 154, 87-97. [CrossRef]

57. Hollmann, F.; Grzebyk, P.; Heinrichs, V.; Doderer, K.; Thum, O. On the inactivity of Candida antartica lipase B towards strong acids. J. Mol. Catal. B 2009, 57, 257-261. [CrossRef] 
58. Kamzolova, S.V.; Fatykhova, A.R.; Dedyukhina, E.G.; Anastassiadis, S.G.; Golovchenko, N.P.; Morgunov, I.G. Citric Acid Production by Yeast Grown on Glycerol-Containing Waste from Biodiesel Industry. Food Technol. Biotechnol. 2011, 49, 65-74.

59. Tamakawa, H.; Ikushima, S.; Yoshida, S. Efficient production of l-lactic acid from xylose by a recombinant Candida utilis strain. J. Biosci. Bioeng. 2012, 113, 73-75. [CrossRef] [PubMed]

60. Thakker, C.; Martínez, I.; Li, W.; San, K.-Y.; Bennett, G.N. Metabolic engineering of carbon and redox flow in the production of small organic acids. J. Ind. Microbiol. Biotechnol. 2015, 42, 403-422. [CrossRef] [PubMed]

61. Do, D.T.H.; Theron, C.W.; Fickers, P. Organic Wastes as Feedstocks for Non-Conventional Yeast-Based Bioprocesses. Microorganisms 2019, 7, 229. [CrossRef] [PubMed]

62. Galaction, A.I.; Cascaval, D.; Oniscu, C.; Turnea, M. Prediction of oxygen mass transfer coefficients in stirred bioreactors for bacteria, yeasts and fungus broths. Biochem. Eng. J. 2004, 20, 85-94. [CrossRef]

63. Klein, M.; Islam, Z.-U.; Knudsen, P.B.; Carrillo, M.; Swinnen, S.; Workman, M.; Nevoigt, E. The expression of glycerol facilitators from various yeast species improves growth on glycerol of Saccharomyces cerevisiae. Metab. Eng. Commun. 2016, 3, 252-257. [CrossRef] [PubMed]

64. Kamzolova, S.V.; Morgunov, I.G. Metabolic peculiarities of the citric acid overproduction from glucose in yeasts Yarrowia lipolytica. Bioresour. Technol. 2017, 243, 433-440. [CrossRef]

65. Morgunov, I.G.; Kamzolova, S.V.; Lunina, J.N. The citric acid production from raw glycerol by Yarrowia lipolytica yeast and its regulation. Appl. Microbiol. Biotechnol. 2013, 97, 7387-7397. [CrossRef]

66. Morgunov, I.G.; Kamzolova, S.V.; Lunina, J.N. Citric Acid Production by Yarrowia lipolytica Yeast on Different Renewable Raw Materials. Fermentation 2018, 4, 36. [CrossRef]

67. Morgunov, I.G.; Kamzolova, S.V. Physiologo-biochemical characteristics of citrate-producing yeast Yarrowia lipolytica grown on glycerol-containing waste of biodiesel industry. Appl. Microbiol. Biotechnol. 2015, 99, 6443-6450. [CrossRef] [PubMed]

68. Rzechonek, D.A.; Dobrowolski, A.; Rymowicz, W.; Mironczuk, A.M. Aseptic production of citric and isocitric acid from crude glycerol by genetically modified Yarrowia lipolytica. Bioresour. Technol. 2019, 271, 340-344. [CrossRef] [PubMed]

69. Kamzolova, S.V.; Morgunov, I.G. Biosynthesis of pyruvic acid from glycerol-containing substrates and its regulation in the yeast Yarrowia lipolytica. Bioresour. Technol. 2018, 266, 125-133. [CrossRef] [PubMed]

70. Mirończuk, A.M.; Dobrowolski, A.; Rakicka, M.; Rywińska, A.; Rymowicz, W. Newly isolated mutant of Yarrowia lipolytica MK1 as a proper host for efficient erythritol biosynthesis from glycerol. Process Biochem. 2015, 50, 61-68. [CrossRef]

71. Visser, W.; Scheffers, W.A.; Batenburg-van der Vegte, W.H.; van Dijken, J.P. Oxygen requirements of yeasts. Appl. Env. Microbiol. 1990, 56, 3785.

72. Jost, B.; Holz, M.; Aurich, A.; Barth, G.; Bley, T.; Müller, R.A. The influence of oxygen limitation for the production of succinic acid with recombinant strains of Yarrowia lipolytica. Appl. Microbiol. Biotechnol. 2015, 99, 1675-1686. [CrossRef]

73. Lee, S.Y.; Hong, S.H.; Lee, S.H.; Park, S.J. Fermentative production of chemicals that can be used for polymer synthesis. Macromol. Biosci. 2004, 4, 157-164. [CrossRef]

74. Bai, S.; Dai, J.; Xia, M.; Ruan, J.; Wei, H.; Yu, D.; Li, R.; Jing, H.; Tian, C.; Song, L.; et al. Effects of intermediate metabolite carboxylic acids of TCA cycle on Microcystis with overproduction of phycocyanin. Environ. Sci. Pollut. Res. Int. 2015, 22, 5531-5537. [CrossRef]

75. Yuzbashev, T.V.; Yuzbasheva, E.Y.; Sobolevskaya, T.I.; Laptev, I.A.; Vybornaya, T.V.; Larina, A.S.; Matsui, K.; Fukui, K.; Sineoky, S.P. Production of succinic acid at low $\mathrm{pH}$ by a recombinant strain of the aerobic yeast Yarrowia lipolytica. Biotechnol. Bioeng. 2010, 107, 673-682. [CrossRef]

(C) 2019 by the authors. Licensee MDPI, Basel, Switzerland. This article is an open access article distributed under the terms and conditions of the Creative Commons Attribution (CC BY) license (http://creativecommons.org/licenses/by/4.0/). 